\title{
Strategi Peningkatan Ketahanan Pangan Kabupaten Bogor
}

\author{
Strategy to Increase Food Security in Bogor Regency \\ Syifa Putri Kusumaningrum*) \\ Yusman Syaukat \\ Muhammad Firdaus
}

\begin{abstract}
Manajemen Pembangunan Daerah, Sekolah Pascasarjana IPB Bogor, Jawa Barat, Indonesia

${ }^{*}$ Email: syifaputridarik@gmail.com
\end{abstract}

\begin{abstract}
The agricultural sector in Bogor Regency is facing probems, namely land conversion and stagnant productivity. This problem causes rice production to be not optimal so that the main food independence in Bogor Regency cannot be achieved. This study aims to formulate a strategy to increase food security in Bogor Regency. The method used in this research is descriptive analysis, multiple regression, SWOT and QSPM. The results of multiple regression analysis show that productivity has a significant effect on rice production in Bogor Regency, while land conversion does not have a significant effect. The SWOT formulation resulted in several strategic formulations, including cooperation with other regions with a surplus of rice, empowering agricultural-human resources, revitalizing agriculture, stopping land conversion, and improving crosssectoral program synergy. The results of the QSPM analysis with the highest TAS value are stop land conversion.
\end{abstract}

Keywords: Food Security, Land Conversion, Rice Production, Regression, SWOT

\begin{abstract}
ABSTRAK
Sektor pertanian di Kabupaten Bogor mengalami permasalahan berupa peningkatan konversi lahan sawah dan produktivitas padi yang cenderung tidak meningkat. Permasalahan ini menyebabkan produksi padi menjadi tidak optimal sehingga tidak tercapai kemandirian pangan utama di Kabupaten Bogor. Penelitian ini bertujuan untuk merumuskan strategi peningkatan ketahanan pangan Kabupaten Bogor. Metode yang digunakan dalam penelitian ini adalah analisis deskriptif, regresi berganda, SWOT dan QSPM. Hasil analisis regresi berganda menunjukkan bahwa produktivitas berpengaruh signifikan terhadap produksi padi di Kabupaten Bogor, sedangkan konversi lahan tidak berpengaruh signifikan. Perumusan SWOT menghasilkan beberapa rumusan strategis, antara lain kerjasama dengan daerah lain yang surplus beras, pemberdayaan SDM pertanian, revitalisasi pertanian, penghentian konversi lahan, dan peningkatan sinergi program lintas sektor. Hasil analisis QSPM dengan nilai TAS tertinggi adalah menghentikan alih fungsi lahan.
\end{abstract}

Kata Kunci: Ketahanan Pangan, Konversi Lahan , Produksi Padi, Regresi, SWOT 


\section{PENDAHULUAN}

\section{Latar Belakang}

Pangan merupakan kebutuhan dasar utama bagi manusia yang harus dipenuhi setiap saat. Hak atas pangan merupakan salah satu hak asasi manusia, sebagaimana diamanatkan di dalam pasal 27 UUD 1945 maupun dalam UU No. 18/2012 tentang Pangan. Bagi Indonesia, pangan sering diidentikkan dengan beras karena jenis pangan ini merupakan makanan pokok utama sebagian besar masyarakat Indonesia. Sektor pertanian memiliki peranan strategis terhadap perekonomian nasional dalam menyediakan pangan bagi masyarakat (Kuncoro dan Sumodiningrat 1991). Namun, sejak 1990-an sektor pertanian Indonesia telah dikarakterisasi oleh stagnasi dan produktivitas pangan relatif tidak mengalami peningkatan (World Bank 2010). Hal tersebut ditunjukkan melalui produksi, produktivitas, dan luas lahan sawah, yang menunjukkan kecenderungan menurun ataupun tidak meningkat, sebagaimana ditunjukkan Tabel 1.

Tabel 1 menunjukkan kondisi produksi, produktivitas dan luas panen padi nasional pada 2010-2019. Rata - rata laju produksi menurun sebanyak 1,59\% per tahun. Produktivitas padi cenderung stagnan dengan rata - rata peningkatan produktivitas sebesar $0,24 \%$ per tahun. Rata - rata pertumbuhan luas lahan sawah adalah $-0,71 \%$ per tahun. Perubahan faktor produktivitas berupa peningkatan ataupun penurunan memberikan pengaruh yang lebih signifikan terhadap produksi padi nasional dibandingkan perubahan faktor luas lahan sawah. Penurunan luas lahan sawah yang tidak siginifikan, tidak berpengaruh terhadap penurunan produksi padi nasional.

Tabel 1 Produksi, Produktivitas dan Luas Lahan Sawah Indonesia 2010-2020

\begin{tabular}{ccccccc}
\hline Tahun & $\begin{array}{c}\text { Produksi } \\
\text { Padi (Ton) }\end{array}$ & $\begin{array}{c}\text { Rata - Rata } \\
\text { Laju } \\
\text { Produksi } \\
\text { Padi (\%) }\end{array}$ & $\begin{array}{c}\text { Produktivitas } \\
\text { Padi } \\
(\mathrm{Ku} / \mathrm{Ha})\end{array}$ & $\begin{array}{c}\text { Rata - Rata } \\
\text { Laju } \\
\text { Produktivitas } \\
\text { Padi (\%) }\end{array}$ & $\begin{array}{c}\text { Luas } \\
\text { Lahan } \\
\text { Sawah } \\
(\mathrm{Ha})\end{array}$ & $\begin{array}{c}\text { Rata - Rata } \\
\text { Laju Luas } \\
\text { Lahan } \\
\text { Sawah (\%) }\end{array}$ \\
\hline 2010 & 66.469 .394 & - & 50,15 & - & 8.003 .213 & - \\
2011 & 65.756 .904 & $-1,07$ & 49,8 & $-0,70$ & 8.094 .862 & 1,15 \\
2012 & 69.056 .126 & 5,02 & 51,36 & 3,13 & 8.132 .345 & 0,46 \\
2013 & 71.279 .709 & 3,22 & 51,52 & 0,31 & 8.112 .103 & $-0,25$ \\
2014 & 70.846 .465 & $-0,61$ & 51,35 & $-0,33$ & 8.116 .641 & 0,06 \\
2015 & 75.397 .841 & 6,42 & 53,41 & 4,01 & 8.087 .393 & $-0,36$ \\
2016 & 79.354 .767 & 5,25 & 52,36 & $-1,97$ & 8.200 .000 & 1,39 \\
2017 & 81.148 .594 & 2,26 & 51,65 & $-1,36$ & 7.750 .000 & $-5,49$ \\
2018 & 59.200 .533 & $-27,05$ & 52,03 & 0,74 & 7.100 .000 & $-8,39$ \\
2019 & 54.604 .033 & $-7,76$ & 51,14 & $-1,71$ & 7.460 .000 & 5,07 \\
\hline Rata-rata & & $-1,59$ & \multicolumn{3}{c}{0.24} & $-0,71$ \\
\hline
\end{tabular}

Sumber: (BPS dan Kementerian Pertanian 2021)

Permasalahan sektor pertanian untuk tanaman pangan tidak terkecuali dialami oleh Kabupaten Bogor. Letaknya sebagai penyangga Jakarta menjadikan sektor pertanian pada daerah ini melambat pertumbuhannya ataupun cenderung menurun. Hal ini ditandai dengan luas lahan sawah Kabupaten Bogor yang memiliki kecenderungan menurun, sebagaimana ditunjukkan oleh Tabel 2. 
Berdasarkan Tabel 2, dapat diketahui kondisi produksi padi, luas sawah dan produktivitas padi selama 16 tahun terakhir. Produksi padi Kabupaten Bogor meningkat sebanyak $2,61 \%$ per tahun. Laju lahan sawah per tahun adalah $-1,57 \%$. Produktivitas padi per tahun sebesar $1,23 \%$ per tahun.

Tabel 2 Produksi, Produktivitas dan Luas Lahan Sawah Kabupaten Bogor 2010-2019

\begin{tabular}{ccccccc}
\hline Tahun & $\begin{array}{c}\text { Produksi } \\
\text { Padi } \\
\text { (Ton) }\end{array}$ & $\begin{array}{c}\text { Rata - Rata } \\
\text { Laju } \\
\text { Produksi } \\
\text { Padi }(\%)\end{array}$ & $\begin{array}{c}\text { Produktivitas } \\
\text { Padi } \\
(\mathrm{Ku} / \mathrm{Ha})\end{array}$ & $\begin{array}{c}\text { Rata - Rata } \\
\text { Laju } \\
\text { Produktivitas } \\
\text { Padi } \%)\end{array}$ & $\begin{array}{c}\text { Luas } \\
\text { Sawah } \\
\text { (Ha) }\end{array}$ & $\begin{array}{c}\text { Rata - Rata } \\
\text { Laju Luas } \\
\text { Lahan (\%) }\end{array}$ \\
\hline 2003 & 373.421 & - & 51,8 & - & 48.177 & - \\
2004 & 445.958 & 19,42 & 52,5 & 1,35 & 47.503 & $-1,40$ \\
2005 & 412.084 & $-7,60$ & 53,7 & 2,29 & 48.598 & 2,31 \\
2006 & 479.755 & 16,42 & 54 & 0,56 & 48.425 & $-0,36$ \\
2007 & 401.066 & $-16,40$ & 57,3 & 6,11 & 48.321 & $-0,21$ \\
2008 & 480.211 & 19,73 & 59,1 & 3,14 & 48.888 & 1,17 \\
2009 & 505.979 & 5,37 & 61,5 & 4,06 & 48.766 & $-0,25$ \\
2010 & 542.895 & 7,30 & 61,9 & 0,65 & 48.484 & $-0,58$ \\
2011 & 519.676 & $-4,28$ & 62,3 & 0,65 & 48.185 & $-0,62$ \\
2012 & 543.481 & 4,58 & 64,75 & 3,93 & 47.932 & $-0,53$ \\
2013 & 596.727 & 9,80 & 60,41 & $-6,70$ & 47.663 & $-0,56$ \\
2014 & 515.233 & $-13,66$ & 60,08 & $-0,55$ & 46.583 & $-2,27$ \\
2015 & 488.926 & $-5,11$ & 63,42 & 5,56 & 45.798 & $-1,69$ \\
2016 & 583.841 & 19,41 & 63,89 & 0,74 & 46.192 & 0,86 \\
2017 & 540.800 & $-7,37$ & 60 & $-6,09$ & 47.152 & 2,08 \\
2018 & 543.715 & 0,54 & 63,06 & 5,10 & 46.785 & $-0,78$ \\
2019 & 509.121 & $-6,36$ & 62,35 & $-1,13$ & 36.355 & $-22,29$ \\
Rata-rata & & 2,61 & & 1,23 & & $-1,57$ \\
\hline
\end{tabular}

Sumber: (BPS dan Distanhorbun 2020)

Luas sawah yang menurun dan produktivitas yang cenderung stagnan menyebabkan hilangnya kapasitas produksi padi dari yang seharusnya. Menurut Hafsah dan Sudaryanto dalam Kasryno et al. (2004), konversi lahan sawah yang terus berlangsung dan tidak segera diatasi akan memicu penurunan produksi padi; sementara pertambahan jumlah penduduk dan peningkatan kesejahteraan mereka menyebabkan peningkatan kebutuhan beras secara terus menerus.

Permasalahan ini berdampak pada defisit-nya ketersediaan pangan beras di Kabupaten Bogor. Di tahun 2018, terjadi defisit beras sebesar 37\% dibandingkan dengan total kebutuhan beras bagi masyarakat di 40 kecamatan di Kabupaten Bogor. Pada 2023, diproyeksikan Kabupaten Bogor akan mengalami defisit beras sebesar 52,28\%, sebagaimana ditunjukkan oleh Gambar 1 (RPJMD Kabupaten Bogor 2018-2023 2018). 


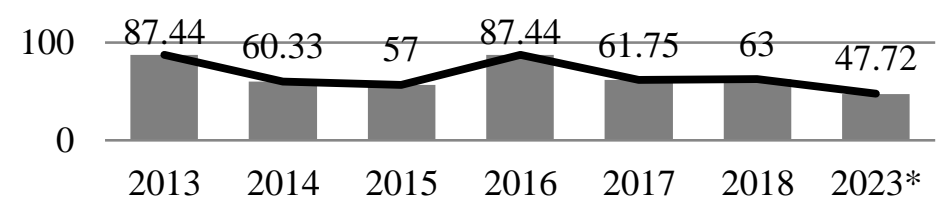

Sumber: LKPJ AMJ Bupati Bogor Periode Tahun 2013 - 2018 dalam RPJMD Kabupaten Bogor 2018 - 2023

Gambar 1 Ketersediaan Pangan Beras Kabupaten Bogor 2013 - 2018

Dengan demikian diproyeksikan hingga 2023 Kabupaten Bogor belum dapat memenuhi kebutuhan pangannya secara mandiri. Artinya kemandirian pangan daerah belum dapat tercapai, bahkan terus mengalami penurunan. Berdasarkan uraian permasalahan tersebut maka didapatkan pertanyaan penelitian yaitu "bagaimana strategi peningkatan ketahanan pangan Kabupaten Bogor?"

\section{Tujuan}

Tujuan penelitian yang akan dijawab dalam kajian ini adalah sebagai berikut.

1. Menganalisis laju perkembangan produksi padi dan keterkaitan antara produksi padi, luas lahan dan produktivitas Kabupaten Bogor

2. Memproyeksikan peluang pemenuhan pangan (kemandirian pangan) Kabupaten Bogor hingga 2025

3. Merumuskan rekomendasi strategi peningkatan ketahanan pangan di Kabupaten Bogor

\section{METODOLOGI PENELITIAN}

\section{Lokasi dan Waktu Penelitian}

Data primer dikumpulkan pada bulan Desember 2020 sampai dengan Februari 2021. Penelitian dilakukan di Kabupaten Bogor. Lokasi dipilih secara sengaja dengan pertimbangan bahwa lokasi tersebut merupakan wilayah pertanian suburban dengan permasalahan tingginya laju pertumbuhan penduduk yang menyebabkan terjadinya alih fungsi lahan pertanian yang relatif tinggi.

\section{Responden Penelitian}

Responden yang dipilih adalah enam staf Dinas Ketahanan Pangan Kabupaten Bogor. Staf tersebut antara lain : Dua Staf dari Bidang Ketersediaan dan Kerawanan Pangan, Dua Staf dari Bidang Distribusi dan Cadangan Pangan, serta Dua Staf dari Bidang Konsumsi dan Penganekaragaman Pangan. Pemilihan responden penelitian menggunakan teknik purposive sampling.

\section{Metode Pengolahan dan Analisis Data}

Data primer dan sekunder yang didapat kemudian diolah dan dianalisis untuk merekomendasikan strategi dan program peningkatan ketahanan pangan Kabupaten 
Bogor. Metode analisis data berdasarkan tujuan penelitian dijelaskan sebagai berikut:

\section{Analisis laju perkembangan produksi padi dan keterkaitan antara produksi padi, luas lahan dan produktivitas}

Dalam rangka menjawab tujuan penelitian pertama, digunakan analisis deskriptif. Analisis deskriptif untuk mendeskripsikan perkembangan produksi padi pada 20032019 di Kabupaten Bogor dan keterkaitan antara produksi padi dengan faktor lainnya. Menurut Sugiyono (2010) statistik deskriptif adalah statistik yang berfungsi untuk mendeskripsikan terhadap obyek yang diteliti melalui data sampel atau populasi sebagaimana adanya, tanpa melakukan analisis dan membuat kesimpulan.

Data yang digunakan untuk menganalisis perkembangan produksi padi pada 2003-2019 di Kabupaten Bogor dan keterkaitan antara produksi padi dengan faktor lainnya berupa data produksi padi, pengurangan luas lahan sawah sebagai konversi lahan, dan produktivitas padi. Jenis data adalah data sekunder. Sumber data berasal dari Dinas Tanaman Pangan, Holtikultura dan Perkebunan Kabupaten Bogor serta BPS Kabupaten Bogor.

Keterkaitan antara produksi padi dengan faktor lainnya dianalisis menggunakan regresi berganda. Model regresi berganda merupakan model yang mempertimbangkan kemungkinan bahwa ada lebih dari satu variabel penjelas yang mempengaruhi variabel tak bebas (Gujarati 2006). Model regresi berganda dalam penelitian ini adalah:

$$
\text { Prod.Padi } \text { Pa }_{t}+\beta_{1} \text { KonvLS }_{t}+\beta_{2} \operatorname{Prv}_{t}+u_{t}
$$

Keterangan :

Prod.Padi $\quad$ : Jumlah produksi padi (ton) pada 2004-2019

$K_{\text {KonvLS }} \quad$ : Pengurangan antara luas lahan sawah (Ha) pada tahun $\mathrm{t}+1$ dengan luas lahan sawah tahun t Kabupaten Bogor pada 2004-2019

Prvt $\quad$ : Produktivitas (Ton/Ha) Kabupaten Bogor pada 2004-2019

$\beta 0 \quad$ : Intersep

$\beta 1, \beta 2$ : Koefisien estimasi atau slope

$\mathrm{u}_{\mathrm{t}} \quad$ : faktor lain diluar variabel (error)

Hipotesis dalam penelitian ini adalah sebagai berikut:

Konversi luas lahan sawah dan produktivitas berpengaruh secara nyata terhadap produksi padi Kabupaten Bogor.

\section{Proyeksi peluang pemenuhan pangan (kemandirian pangan) Kabupaten Bogor hingga 2025}

Metode analisis yang digunakan untuk menjawab tujuan penelitian kedua adalah deskriptif kuantitatif. Perkiraan pemenuhan kemandirian pangan Kabupaten Bogor dilakukan melalui tiga tahap perhitungan. Pertama dengan memproyeksikan konsumsi beras. Kedua dengan memproyeksikan produksi beras. Ketiga hasil proyeksi dibuat neraca antara konsumsi beras dengan ketersediaan beras untuk mengetahui kondisi kemandirian pangan beras. 
Proyeksi konsumsi beras menggunakan data jumlah penduduk dan konsumsi beras per kapita per tahun. Metode yang digunakan untuk proyeksi jumlah penduduk adalah metode geometrik. Proyeksi penduduk dengan metode geometrik menggunakan asumsi bahwa jumlah penduduk akan bertambah menurut deret geometrik dengan perhitungan bunga majemuk (Adioetomo dan Samosir 2010 dalam BPS 2010). Laju pertumbuhan penduduk (rate of growth) dianggap sama untuk setiap tahun. Berikut formula yang digunakan pada metode geometrik:

$P_{t}=P_{0}(1+r)^{t}$ dengan $r=\left(\frac{P_{t}}{P_{0}}\right)^{\frac{1}{t}}-1$

Keterangan :

$\mathrm{P}_{\mathrm{t}} \quad=$ jumlah penduduk pada tahun $\mathrm{t}$

$\mathrm{P}_{0} \quad=$ jumlah penduduk pada tahun dasar

$\mathrm{r} \quad=$ laju pertumbuhan penduduk

$\mathrm{t} \quad=$ periode waktu antara tahun dasar dan tahun $\mathrm{t}$ (dalam tahun)

Peramalan produksi beras menggunakan analisis deret berkala. Analisis deret berkala adalah prosedur analisis untuk mengetahui perkembangan nilai suatu variabel sebagai akibat dari perubahan waktu (Sujalu et al. 2021). Berikut rumus untuk menentukan trend:

$Y=a+b(x)$

Keterangan:

$\mathrm{Y} \quad=$ nilai variable produksi beras pada suatu waktu tertentu

a $\quad=$ perpotongan antara garis trend dengan sumbu tegak (Y)

$\mathrm{b} \quad=$ kemiringan (slope) garis trend

$\mathrm{x} \quad=$ periode waktu deret berkala

\section{Perumusan strategi dan program Kabupaten Bogor dalam upaya untuk meningkatkan kemandirian pangan}

Perumusan rekomendasi strategi peningkatan ketahanan pangan Kabupaten Bogor menggunakan analisis SWOT. Menurut David (2017), analisis SWOT digunakan untuk mengidentifikasi faktor-faktor internal berupa kekuatan (strengths) dan kelemahan (weaknesses), serta faktor eksternal berupa peluang (opportunities) dan ancaman (threats). Tahapan dalam rumusan strategi terdiri dari tiga tahap.

Pada Tahap I, ditentukan faktor internal dan eksternal yang berpengaruh terhadap strategi peningkatan ketahanan pangan Kabupaten Bogor. Data dikelompokkan dalam Matriks Internal Strategic Factor Analysis Summary (IFAS) dan Matriks External Strategic Factor Analysis Summary (EFAS). Data diperoleh melalui wawancara dengan kuesioner kepada 6 staf ahli Dinas Ketahanan Pangan Kabupaten Bogor dan Renstra Dinas Ketahanan Pangan Kabupaten Bogor pada 2018 - 2023. Matriks IFAS digunakan untuk mengevaluasi kekuatan dan kelemahan utama dalam fungsi-fungsi internal Dinas Ketahanan Pangan Kabupaten Bogor. Matriks EFAS untuk identifikasi peluang dan ancaman dari luar Dinas Ketahanan Pangan Kabupaten Bogor dalam pencapaian tujuan. Setelah mengidentifikasi IFAS dan EFAS dilakukan Tahap II. Tahap II adalah perumusan strategi dengan pencocokkan komponen S,W,O,T dengan 
matriks SWOT. Tahap III adalah penetapan strategi prioritas dengan QSPM.

\section{HASIL PENELITIAN DAN PEMBAHASAN}

\section{Laju Perkembangan Produksi Padi}

\section{Produksi Padi}

Berdasarkan Tabel 3 diketahui bahwa perkembangan produksi padi Kabupaten Bogor cenderung berfluktuasi. Produksi padi meningkat pada 2003-2013 dan menurun pada 2016-2019. Rata - rata peningkatan laju produksi padi pada 2003-2013 adalah 2,57\% per tahun. Rata - rata laju produksi padi pada 2003 - 2019 adalah $1,26 \%$ per tahun.

Produksi padi pada 2017 menurun disebabkan terjadi gagal panen akibat musim kemarau panjang di awal tahun. Pada 2018 terjadi peningkatan produksi padi disebabkan dukungan APBD. Beberapa program peningkatan produksi yang dilakukan antara lain: kegiatan pengembangan PTT padi, kegiatan pengendalian hama terpadu padi, kegiatan pengadaan sarana produksi tanaman pangan, kegiatan penangkar benih padi, kegiatan pengadaan alat pasca panen padi serta kegiatan fasilitas penerapan budidaya padi.

Tabel 3. Produksi Padi Kabupaten Bogor 2003-2019

\begin{tabular}{cccccc}
\hline Tahun & $\begin{array}{c}\text { Produksi } \\
\text { Padi } \\
\text { (Ton) }\end{array}$ & $\begin{array}{c}\text { Rata }- \\
\text { Rata Laju } \\
\text { Produksi } \\
\text { Padi (\%) }\end{array}$ & Tahun & $\begin{array}{c}\text { Produksi } \\
\text { Padi } \\
\text { (Ton) }\end{array}$ & $\begin{array}{c}\text { Rata - } \\
\text { Rata Laju } \\
\text { Produksi } \\
\text { Padi (\%) }\end{array}$ \\
\hline 2003 & 373.421 & - & 2012 & 543.481 & $4,58 \%$ \\
2004 & 445.958 & $19,42 \%$ & 2013 & 596.727 & $9,80 \%$ \\
2005 & 412.084 & $-7,60 \%$ & 2014 & 515.233 & $-13,66 \%$ \\
2006 & 479.755 & $16,42 \%$ & 2015 & 488.926 & $-5,11 \%$ \\
2007 & 401.066 & $-16,40 \%$ & 2016 & 583.841 & $19,41 \%$ \\
2008 & 480.211 & $19,73 \%$ & 2017 & 540.800 & $-7,37 \%$ \\
2009 & 505.979 & $5,37 \%$ & 2018 & 543.715 & $0,54 \%$ \\
2010 & 542.895 & $7,30 \%$ & 2019 & 509.121 & $-6,36 \%$ \\
2011 & 519.676 & $-4,28 \%$ & & & \\
\hline Rata - Rata Laju Produksi Padi (\%) per tahun & $2,61 \%$ \\
\hline
\end{tabular}

Sumber: (BPS dan Distanhorbun 2020)

\section{Luas Lahan Sawah}

Tabel 4 menunjukkan alih fungsi lahan sawah di Kabupaten Bogor cenderung meningkat dalam 16 tahun terakhir. Persentase penurunan luas sawah terbesar terjadi pada 2019 yaitu menurun sebanyak 22\% dibandingkan 2018. Luas sawah pada 2019 menurun sebanyak $25 \%$ bila dibandingkan luas sawah pada 2003. Laju luas lahan pada 2003-2019 adalah $-1,43 \%$ per tahun. 
Tabel 4. Luas Lahan Sawah Kabupaten Bogor 2003-2019

\begin{tabular}{cccccc}
\hline Tahun & $\begin{array}{c}\text { Luas } \\
\text { Sawah } \\
\text { (Ha) }\end{array}$ & $\begin{array}{c}\text { Rata } \\
\text { Rata Laju } \\
\text { Luas } \\
\text { Lahan } \\
(\%)\end{array}$ & Tahun & $\begin{array}{c}\text { Luas } \\
\text { Sawah } \\
\text { (Ha) }\end{array}$ & $\begin{array}{c}\text { Rata } \\
\text { Rata Laju } \\
\text { Luas } \\
\text { Lahan } \\
(\%)\end{array}$ \\
\hline 2003 & 48.177 & $-1,4 \%$ & 2012 & 47.932 & $-0,53 \%$ \\
2004 & 47.503 & $-1,40 \%$ & 47.663 & $-0,56 \%$ \\
2005 & 48.598 & $2,31 \%$ & 2014 & 46.583 & $-2,27 \%$ \\
2006 & 48.425 & $-0,36 \%$ & 2015 & 45.798 & $-1,69 \%$ \\
2008 & 48.321 & $-0,21 \%$ & 2016 & 46.192 & $0,86 \%$ \\
2009 & 48.888 & $1,17 \%$ & 2017 & 47.152 & $2,08 \%$ \\
2010 & 48.766 & $-0,25 \%$ & 2018 & 46.785 & $-0,78 \%$ \\
2011 & 48.484 & $-0,58 \%$ & 2019 & 36.355 & $-22,29 \%$ \\
\hline \multicolumn{7}{c}{ Rata - Rata Laju Luas Lahan $\%$} \\
\hline
\end{tabular}

Sumber: (BPS 2020)

\section{Produktivitas Padi}

Produktivitas padi Kabupaten Bogor cenderung stagnan. Hal ini dapat dilihat dalam Tabel 5. Produktivitas padi pada 2003-2019 mengalami peningkatan produktivitas rata rata sebesar 1,24\% per tahun. Pada 2018 terjadi peningkatan produktivitas bila dibandingkan 2017. Peningkatan produktivitas disebabkan adanya penerapan paket teknologi pada sarana produksi berupa pupuk dan benih unggul bersertifikat.

Tabel 5. Produktivitas Kabupaten Bogor 2003-2019

\begin{tabular}{|c|c|c|c|c|c|}
\hline Tahun & $\begin{array}{c}\text { Produktivi } \\
\text { tas Padi } \\
\text { (Ku/Ha) }\end{array}$ & $\begin{array}{c}\text { Rata - } \\
\text { Rata Laju } \\
\text { Produktivi } \\
\text { tas Padi } \\
(\%)\end{array}$ & Tahum & $\begin{array}{l}\text { Produktivi } \\
\text { tas Padi } \\
\text { (Ku/Ha) }\end{array}$ & $\begin{array}{c}\text { Rata - } \\
\text { Rata Laju } \\
\text { Produktivi } \\
\text { tas Padi } \\
(\%)\end{array}$ \\
\hline 2003 & 51,8 & - & 2012 & 64,75 & 3,93 \\
\hline 2004 & 52,5 & 1,35 & 2013 & 60,41 & $-6,70$ \\
\hline 2005 & 53,7 & 2,29 & 2014 & 60,08 & $-0,55$ \\
\hline 2006 & 54 & 0,56 & 2015 & 63,42 & 5,56 \\
\hline 2007 & 57,3 & 6,11 & 2016 & 63,89 & 0,74 \\
\hline 2008 & 59,1 & 3,14 & 2017 & 60 & $-6,09$ \\
\hline 2009 & 61,5 & 4,06 & 2018 & 63,06 & 5,10 \\
\hline 2010 & 61,9 & 0,65 & 2019 & 62,35 & $-1,13$ \\
\hline 2011 & 62,3 & 0,65 & & & \\
\hline \multicolumn{5}{|c|}{ Rata - Rata Laju Produktivitas (\%) } & $1,23 \%$ \\
\hline
\end{tabular}

Sumber: (BPS dan Distanhorbun 2020)

Berdasarkan pengamatan terhadap perkembangan produksi padi dalam Tabel 3, 4 dan 5 diketahui bahwa faktor produktivitas lebih berperan dalam meningkatkan produksi padi. Apabila luas lahan sawah menurun, produksi padi tidak selalu mengalami penurunan. Hal ini disebabkan terdapat program yang meningkatkan produktivitas padi. Namun, ketika produktivitas menurun, produksi padi ikut menurun. 


\section{Keterkaitan antara Produksi Padi, Konversi Lahan Sawah dan Produktivitas Kabupaten Bogor}

Keterkaitan antara pengurangan luas lahan sawah (konversi lahan sawah), produktivitas dan produksi padi di Kabupaten Bogor dianalisis dengan regresi berganda. Sebelum diestimasi, model terlebih dahulu diuji dengan asumsi klasik untuk mengetahui apakah model memenuhi kriteria BLUE (Best, Linear, Unbiased, and Estimated). Model melewati uji normalitas, uji heteroskedastisitas, uji autokolerasi, dan uji multikolinearitas. Setelah melawati uji, diketahui bahwa model regresi linear yang diestimasi layak digunakan untuk menjelaskan keterkaitan konversi lahan sawah dan produktivitas dengan produksi padi.

Hasil regresi ditunjukkan oleh Tabel 6. Berdasarkan Tabel 6, secara parsial variabel produktivitas berpengaruh secara signifikan terhadap produksi padi, ditunjukkan oleh tingkat signifikasi $0,003>$ dari $\alpha=5 \%$. Sedangkan variabel konversi lahan tidak berpengaruh secara signifikan terhadap produksi padi, dengan tingkat signifikasi 0,589 $>$ dari $\alpha=5$ persen.

Tabel 6 Ringkasan analisis regresi linear berganda untuk model keterkaitan antara konversi lahan sawah dan produktivitas dengan produksi padi sebagai variabel terikat

\begin{tabular}{|c|c|c|c|}
\hline Variabel & $\begin{array}{l}\text { Koefisien } \\
\text { regresi }\end{array}$ & $t_{\text {hitung }}$ & Sig. \\
\hline Konstanta & -120.408 & & \\
\hline Konversi Lahan Sawah (X1) & $-2,278$ & $-0,55$ & 0,589 \\
\hline Produktivitas (X2) & 10.479 & 3,64 & 0,003 \\
\hline $\begin{array}{l}F_{\text {hitung }}=6,648>F_{\text {tabel }} \\
\text { R Square }=0,506\end{array}$ & $(2 ; 13)=3,81$ & & 0,001 \\
\hline
\end{tabular}

Sumber: data diolah (2021)

Hasil $\mathrm{R}$ square adalah 0,506. Hasil tersebut menunjukkan variabel luas lahan dan produktivitas mampu menjelaskan pengaruhnya terhadap produksi padi sebanyak $50,6 \%$, sedangkan sisanya dijelaskan oleh variabel lain diluar penelitian. Berdasarkan Tabel 7 model regresi yang didapatkan adalah sebagai berikut:

$$
\text { Prod. } \text { Padi }=-120.408-2,28 \text { KonvLS }_{t}+10.479 \text { Prv }_{t}+e
$$

Koefisien regresi untuk variabel konversi lahan sawah sebesar -2,28 dan variabel produktivitas sebesar 10.479. Koefisien regresi konversi lahan sawah bernilai negatif artinya pada saat konversi lahan sawah meningkat maka jumlah produksi padi akan mengalami penurunan. Kenaikan konversi lahan sawah sebesar $1 \mathrm{Ha}$ akan menurunkan jumlah produksi padi sebanyak 2,28 ton dan penurunan konversi lahan sawah sebesar 1 Ha akan meningkatkan jumlah produksi padi sebanyak 2,28 ton.

Koefisien regresi produktivitas bernilai positif. Pada saat produktivitas meningkat maka jumlah produksi padi akan mengalami peningkatan. Begitu pula pada saat produktivitas menurun maka jumlah produksi padi juga menurun. Kenaikan produktivitas sebesar 1 Ton/Ha akan meningkatkan jumlah produksi padi sebesar 1.047 ton dan penurunan produktivitas sebesar $1 \mathrm{Ton} / \mathrm{Ha}$ akan menurunkan jumlah produksi padi sebesar 1.047 
ton.

Hasil analisis keterkaitan antara produksi padi dengan faktor lainnya adalah produktivitas berpengaruh terhadap produksi padi sedangkan konversi lahan berpengaruh terhadap penurunan produksi beras, namun tidak signifikan. Laju pertumbuhan lahan sawah periode 2004-2019 yang negatif dapat mengancam kemandirian pangan di Kabupaten Bogor pada masa yang akan datang. Hasil kajian ini sama dengan hasil penelitian terdahulu dari R. Destianto dan Pigawati (2014). Penelitian yang dilakukan R. Destianto dan Pigawati (2014) memiliki hasil produktivitas signifikan berpengaruh terhadap produktivitas padi, sementara konversi lahan tidak berpengaruh secara signifikan terhadap produksi padi. Namun dalam jangka waktu yang panjang konversi lahan dapat mempengaruhi ketahanan pangan.

\section{Proyeksi peluang pemenuhan pangan (kemandirian pangan) Kabupaten Bogor hingga 2025}

Sebelum meramalkan kemandirian pangan kabupaten Bogor pada 2025 terlebih dahulu dilakukan proyeksi penduduk, proyeksi konsumsi beras dan proyeksi produksi beras. Berdasarkan perhitungan dengan metode geometrik didapatkan proyeksi penduduk pada 2025 sebanyak 6.741.338 jiwa. Kemudian proyeksi konsumsi beras didapat dengan mengalikan jumlah penduduk hasil proyeksi dengan jumlah konsumsi beras per kapita per tahun di Kabupaten Bogor sebesar 114,6 kg. Hasil proyeksi konsumsi beras empat tahun ke depan adalah 772.557 ton.

Berdasarkan analisis trend, didapat persamaan sebagai berikut:

$$
\mathrm{Y}=10.187 .858,19-4.885,71 \mathrm{x}
$$

Dengan memasukkan tahun 2025 dalam persamaan, akan didapatkan proyeksi produksi beras. Hasilnya adalah pada 2025 diperkirakan produksi beras Kabupaten Bogor sebesar 294.295 ton. Rincian perhitungan proyeksi 2021-2025 terdapat dalam Tabel 7.

Berdasarkan Tabel 7, diketahui bahwa pada 2021-2025 Kabupaten Bogor akan mengalami penurunan kemandirian pangan. Bukannya mengalami peningkatan kemandirian pangan, namun malah semakin menurun pada 2020 hingga 2025. Hal ini ditandai dengan kondisi pemenuhan pangan pada 2020 mencapai 45,68\% menjadi 38\% pada 2025. Kondisi kemandirian pangan beras empat tahun ke depan diperkirakan menjadi defisit pangan beras sebesar $62 \%$. Permasalahan ini dapat membahayakan ketahanan pangan Kabupaten Bogor. 
Tabel 7. Proyeksi Produksi, Konsumsi dan Kemandirian Beras Kabupaten Bogor, tahun 2021-2025

\begin{tabular}{|c|c|c|c|c|c|c|}
\hline Tahun & $\begin{array}{c}\text { Jumlah } \\
\text { Penduduk }\end{array}$ & $\begin{array}{c}\text { Konsumsi } \\
\text { per Kapita } \\
\text { (ton) }\end{array}$ & $\begin{array}{c}\text { Produksi } \\
\text { Beras } \\
\text { (ton) }\end{array}$ & $\begin{array}{c}\text { Konsumsi } \\
\text { Beras } \\
\text { (ton) }\end{array}$ & $\begin{array}{l}\text { Selisih } \\
\text { (ton) }\end{array}$ & $\begin{array}{c}\% \\
\text { Kemandirian }\end{array}$ \\
\hline 2014 & 5.331 .149 & 0,1146 & 356.261 & 610.950 & -254.689 & 58,31 \\
\hline 2015 & 5.459 .668 & 0,1146 & 311.721 & 625.678 & -313.957 & 49,82 \\
\hline 2016 & 5.587 .390 & 0,1146 & 369.434 & 640.315 & -270.881 & 57,70 \\
\hline 2017 & 5.715 .009 & 0,1146 & 334.701 & 654.940 & -320.239 & 51,10 \\
\hline 2018 & 5.840 .907 & 0,1146 & 316.837 & 669.368 & -352.531 & 47,33 \\
\hline 2019 & 5.965 .410 & 0,1146 & 325.938 & 683.636 & -357.698 & 47,68 \\
\hline 2020 & 6.088 .233 & 0,1146 & 318.724 & 697.712 & -378.988 & 45,68 \\
\hline $2021 *$ & 6.213 .585 & 0,1146 & 313.838 & 712.077 & -398.239 & 44,07 \\
\hline $2022 *$ & 6.341 .518 & 0,1146 & 308.953 & 726.738 & -417.785 & 42,51 \\
\hline $2023^{*}$ & 6.472 .084 & 0,1146 & 304.067 & 741.701 & -437.634 & 40,99 \\
\hline $2024 *$ & 6.605 .339 & 0,1146 & 299.181 & 756.972 & -457.791 & 39,52 \\
\hline $2025^{*}$ & 6.741 .338 & 0,1146 & 294.295 & 772.557 & -478.262 & 38,09 \\
\hline
\end{tabular}

Keterangan : * hasil proyeksi

\section{Rumusan Strategi Peningkatan Ketahanan Pangan Kabupaten Bogor}

Berdasarkan data wawancara dengan enam informan ahli didapatkan faktor internal dan eksternal yang berpengaruh terhadap kemandirian pangan beras Kabupaten Bogor. Hasilnya diperoleh matriks IFAS dan EFAS dalam Tabel 8 dan Tabel 9. 
Tabel 8 Matriks IFAS

\begin{tabular}{|l|c|c|c|}
\hline \multicolumn{1}{|c|}{ Faktor Internal } & Bobot & Rating & Skor \\
\hline \multicolumn{1}{|c|}{ Kekuatan (Strength) } & & & \\
\hline $\begin{array}{l}\text { 1. Bimbingan teknis (Bimtek) untuk meningkatkan } \\
\text { produktivitas dan mutu beras petani }\end{array}$ & 0,15 & 3,67 & 0,53 \\
\hline 2. Mempunyai kewenangan revitalisasi pertanian & 0,16 & 4 & 0,64 \\
\hline 3. Keamanan pangan & 0,16 & 4 & 0,64 \\
\hline 4. Cadangan Pangan Pemerintah Daerah (CPPD) & 0,16 & 4 & 0,64 \\
\hline 5. Ketersediaan Lumbung Pangan Masyarakat & 0,16 & 4 & 0,64 \\
\hline \multicolumn{1}{|c|}{ Kelemahan (Weakness) } & & & \\
\hline 1. Keterbatasan jumlah SDM & 0,05 & 1,17 & 0,05 \\
\hline $\begin{array}{l}\text { 2. Lingkup kerja yang luas dengan sumber daya yang } \\
\text { terbatas }\end{array}$ & 0,05 & 1,33 & 0,07 \\
\hline 3. Sinergitas lintas sektoral & 0,04 & 1 & 0,04 \\
\hline 4. Kurang fokusnya program/kegiatan & 0,08 & 2 & 0,16 \\
\hline \multicolumn{1}{|c|}{ Total } & 1 & & \\
\hline
\end{tabular}

Sumber: data diolah (2021)

Tabel 9 Matriks EFAS

\begin{tabular}{|l|c|c|c|}
\hline \multicolumn{1}{|c|}{ Faktor Eksternal } & Bobot & Rating & Skor \\
\hline \multicolumn{1}{|c|}{ Peluang (Opportunities) } & & & \\
\hline 1. UU Perlindungan Lahan Pertanian Pangan Berkelanjutan & 0,07 & 2,17 & 0,14 \\
\hline 2. Penciptaan lahan sawah baru & 0,08 & 2,50 & 0,19 \\
\hline 3. Diterapkannya GAP & 0,11 & 3,67 & 0,41 \\
\hline 4. Diadakannya Bimtek GHP \& GMP & 0,11 & 3,67 & 0,41 \\
\hline \multicolumn{1}{|c|}{ Ancaman (Threats) } & & & \\
\hline $\begin{array}{l}\text { 1. Pertumbuhan penduduk Kabupaten Bogor semakin } \\
\text { meningkat }\end{array}$ & 0,08 & 2,67 & 0,22 \\
\hline 2. Adanya impor beras & 0,08 & 2,50 & 0,19 \\
\hline 3. Perubahan iklim & 0,09 & 2,83 & 0,24 \\
\hline 4. Alih fungsi lahan pertanian & 0,12 & 3,80 & 0,44 \\
\hline $\begin{array}{l}\text { 5. Penurunan minat, orientasi dan motivasi usaha pada } \\
\text { angkatan kerja usia muda terhadap usaha tani }\end{array}$ & 0,08 & 2,67 & 0,22 \\
\hline 6. Panjangnya rantai distribusi & 0,10 & 3,17 & 0,30 \\
\hline 7. Belum optimalnya pembinaan ke petani & 0,10 & 3,33 & 0,34 \\
\hline \multicolumn{1}{|c|}{ Total } & 1,00 & & \\
\hline \multicolumn{2}{|c|}{ Sumber: data diah (2021) } \\
\hline
\end{tabular}

Sumber: data diolah (2021)

Berdasarkan penggabungan Matriks IFAS dan EFAS didapatkan Matris SWOT dengan lima rumusan strategi berikut:

a. Strategi S-O (Strengths-Opportunities)

1. Memberdayakan SDM Pertanian

Strategi memperdayakan SDM pertanian dalam meningkatkan kualitas manajemen produk pangan diterapkan sebagai upaya peningkatan produksi padi. Strategi ini memanfaatkan faktor kekuatan Dinas Ketahanan Pangan (DKP) Kabupaten Bogor berupa bimbingan teknis (Bimtek) untuk meningkatkan produktivitas dan mutu beras petani (S1), serta keamanan pangan (S3), untuk menerapkan Sistem OperasionalGood Agriculture Practice (SOP-GAP), Good Handling Practices (GHP) dan Good Manufacturing Practices (GMP) (O3 dan O4). Berdasarkan penelitian yang dilakukan oleh Shofi et al. (2019), Wihardjaka (2018), Soemantri et al. (2016, dan 
Zuwarman et al. (2020) penerapan SOP-GAP, GHP dan GMP berpengaruh secara signifikan terhadap peningkatan produksi padi dan mutu beras.

\section{b. Strategi W-O (Weaknesses-Opportunities)}

1. Menghentikan alih fungsi lahan

DKP Kabupaten Bogor memiliki kelemahan yaitu kurang fokusnya program/kegiatan (W4). Kabupaten Bogor memiliki peluang yaitu UU Perlindungan Lahan Pertanian Pangan Berkelanjutan dan penciptaan lahan sawah baru (O1, O2) Rumusan rekomendasi strategi untuk permasalahan tersebut adalah menghentikan alih fungsi lahan seperti pengawasan terhadap lahan pertanian pangan berkelanjutan yang sudah ditetapkan terutama di wilayah sentra-sentra beras Kabupaten Bogor. Strategi menghentikan alih fungsi lahan untuk meningkatkan ketahanan pangan juga dirumuskan oleh Wahyunto dan Widiastuti (2014).

c. Strategi S-T (Strenghts-Threats)

1. Revitalisasi pertanian

DKP Kabupaten Bogor memiliki faktor kekuatan berupa mempunyai kewenangan revitalisasi pertanian (S2). Faktor ancaman antara lain pertumbuhan penduduk Kabupaten Bogor semakin meningkat (T1), Perubahan iklim (T3), Alih fungsi lahan pertanian (T4) Penurunan minat, orientasi dan motivasi usaha pada angkatan kerja usia muda terhadap usaha tani (T5). Rumusan rekomendasi strategi untuk mengatasi ancaman revitalisasi pertanian dengan program intensifikasi, diversikasi pangan utama dan program petani milenial. Dalam penelitian terdahulu, ketahanan pangan dapat dicapai melalui program intensifikasi dan diversifikasi pangan utama dirumuskan oleh Haryadi (2009).

2. Kerja sama dengan daerah lain yang surplus beras

DKP Kabupaten Bogor memiliki faktor kekuatan Cadangan Pangan Pemerintah Daerah (CPPD) (S4) dan Ketersediaan Lumbung Pangan Masyarakat (S5). Faktor ancaman yang dihadapi antara lain Adanya impor beras (T2) dan Panjangnya rantai distribusi (T6). Rumusan rekomendasi strategi adalah kerja sama dengan daerah lain yang surplus beras untuk memasok ke wilayah Kabupaten Bogor.

\section{d. Strategi W-T (Weaknesses-Threats)}

Peningkatan sinergitas program/kegiatan lintas sektoral

DKP Kabupaten Bogor memiliki kelemahan berupa Keterbatasan jumlah SDM (W1), Lingkup kerja yang luas dengan sumber daya yang terbatas (W2), dan Sinergitas lintas sektoral (W3). Faktor ancaman yang dihadapi antara lain : panjangnya rantai distribusi (T6) dan belum optimalnya pembinaan ke petani (T7). Rumusan rekomendasi strategi adalah peningkatan sinergitas program/kegiatan lintas sektoral seperti Dinas Tanaman Pangan Hortikultura dan Perkebunan-Dinas Ketahanan Pangan (Distanhorbun-DKP) dan Perusahaan Umum Daerah Pasar Tohaga- Dinas Perdagangan dan Perindustrian.

\section{Strategi Prioritas dalam Peningkatan Ketahanan Pangan Kabupaten Bogor}

Tahap selanjutnya dalam pengambilan keputusan adalah menentukan strategi prioritas dengan QSPM. Berdasarkan analisis dengan nilai skor daya Tarik (AS) dan daya Tarik total (TAS), maka didapatkan matriks QSPM dalam Tabel 10. 
Tabel 10 Matriks Analisis QSPM

\begin{tabular}{|l|c|c|}
\hline \multicolumn{1}{|c|}{ Strategi } & TAS & Prioritas \\
\hline Menghentikan alih fungsi lahan & 5,23 & 1 \\
\hline $\begin{array}{l}\text { Kerjasama dengan daerah lain yang surplus } \\
\text { beras }\end{array}$ & 4,99 & 2 \\
\hline Memberdayakan SDM Pertanian & 4,91 & 3 \\
\hline Revitalisasi Pertanian & 4,05 & 4 \\
\hline Sinergitas program lintas sektoral ditingkatkan & 3,61 & 5 \\
\hline
\end{tabular}

Sumber: data diolah (2021)

Berdasarkan tabel 10, diketahui bahwa nilai TAS tertinggi sebesar 5,23 yaitu menghentikan alih fungsi lahan. Fokusnya program Lahan Pangan Pertanian Berkelanjutan dapat menyelamatkan hilangnya kapasitas produksi padi yang terjadi terus menerus. Strategi berikutnya adalah kerja sama dengan daerah lain yang surplus beras dengan nilai 4,99. Kerja sama dari daerah sentra Kabupaten Bogor seperti Tanjungsari, Jonggol, dan Cariu. Kerja sama dengan luar Kabupaten Bogor seperti Kabupaten Cianjur, Karawang, Subang dan Tangerang.

\section{SIMPULAN DAN SARAN}

\section{Simpulan}

Peningkatan produksi padi di Kabupaten Bogor lebih dipengaruhi oleh faktor produktivitas dibandingkan faktor lahan sawah. Namun laju rata - rata sawah yang negatif dapat mengancam kemandirian pangan beras Kabupaten Bogor. Berdasarkan hasil proyeksi, kemandirian pangan Kabupaten Bogor akan semakin menurun pada 2021-2025.

Pada 2025, Kabupaten Bogor diramalkan akan defisit pangan beras sebesar $62 \%$. Peningkatan ketahanan pangan Kabupaten Bogor dapat dicapai melalui 5 rumusan strategi antara lain: perdayakan SDM pertanian, hentikan alih fungsi lahan, revitalisasi pertanian, kerja sama dengan daerah lain yang surplus beras serta peningkatan sinergitas program/kegiatan lintas sektoral. Strategi prioritas adalah menghentikan alih fungsi lahan.

\section{Saran}

Diharapkan Pemerintah Kabupaten Bogor dapat menindaklanjuti UU Perlindungan Lahan Pertanian Pangan Berkelanjutan dalam mencapai ketahanan pangan. Penelitian ini dapat dianalisa lebih lanjut dengan mengukur efektivitas program peningkatan produksi padi untuk meningkatkan ketahanan pangan dari perspektif kelompok tani.

\section{DAFTAR PUSTAKA}

[BPS] Badan Pusat Statistik Kabupaten Bogor. 2020. Kabupaten Bogor dalam Angka 2020. Kabupaten Bogor: BPS. 
[BPS Republik Indonesia] Badan Pusat Statistik Republik Indonesia. 2020. Statistik Indonesia 2020. Jakarta (ID): BPS.

[Bappeda Kabupaten Bogor]. Badan Perencanaan Pembangunan Daerah Kabupaten Bogor. 2019. RPJMD Kabupaten Bogor 2018-2023.

Bulog. 2018. Ketahanan Pangan. http://www.bulog.co.id/ketahananpangan.php. Diakses pada 27 November 2020.

David, Fred R. 2017. Manajemen strategik. Jakarta (ID): Salemba Empat.

Distanhorbun. 2019. Laporan produksi, produktivitas dan luas lahan sawah Kabupaten Bogor.

Gujarati, Damodar N. 2006. Ekonometrika Dasar. Jakarta: Penerbit Erlangga.

Kasryno, Faisal, Effendi Pasandaran dan Achmad M. Fagi. 2004. Ekonomi Padi dan Beras Indonesia. Badan Penelitian dan Pengembangan Pertanian.

Shofi, Afdila Syifa'atus, Titin Agustinas dan Sri Subekti. 2019 Penerapan Good Agriculture Practices (GAP) Pada Usahatani Padi Merah Organik Application Of Good Agriculture Practices (GAP) In Organic Brown Rice Farming. JSEP Vol 12 No 1 Maret 2019.

Soemantri, Agus Supriyatna, Prima Luna dan Irpan Badrul Jamal. 2016 Strategi Peningkatan Produksi Beras Melalui Penekanan Susut Panen dan Pascapanen Dengan Pendekatan Sistem Modeling: Studi Kasus Kabupaten Indramayu, Jawa Barat. Jurnal Informatika Pertanian, Vol. 25 No.2.

Sugiyono. 2010. Statistika untuk Penelitian. Bandung: Alfabeta

Wihardjaka, Anicetus. 2018. Penerapan Model Pertanian Ramah Lingkungan sebagai Jaminan Perbaikan Kuantitas dan Kualitas Hasil Tanaman Pangan. Artikel Balai Penelitian Lingkungan Pertanian Jawa Tengah.

World Bank. 2010. Indonesia Rising. Policy Priorities for 2010 and Beyond.

Zuwarman, Dwi, Sutrisno Suro Mardjan dan Rokhani Hasbullah. 2020 Kesesuaian Good Handling Practices dan Good Manufacturing Practices Terhadap Mutu Gabah dan Beras di Kabupaten Bogor. Jurnal Keteknikan Pertanian Vol.8 No.1.

R. Destianto, and B. Pigawati. 2014. Analisis Keterkaitan Perubahan Lahan Pertanian Terhadap Ketahanan Pangan Kabupaten Magelang Berbasis Model Spatio Temporal SIG. Geoplanning: Journal of Geomatics and Planning, vol. 1, no. 1, pp. 21-32, Mar. 2014.

Sujalu, Akas Pinaringan, Imam Nazarudin Latif, Ismail Bakrie, dan Lisa Astria 
Milasari. 2021. Statistik Ekonomi 1. Yogyakarta: Zahir Publishing.

Tim Penulis LDFEUI (Editor: Adioetomo, Sri M \& Samosir, O B). 2010. Dasar-dasar Demografi. Jakarta: Salemba Empat.

Wahyunto dan Fitri Widiastuti. 2014. Lahan Sawah Sebagai Pendukung Ketahanan Pangan serta Strategi Pencapaian Kemandirian Pangan. Jurnal Sumberdaya Lahan Edisi Khusus, Desember 2014.

Haryadi, Pulung. 2009. Analisis Kebijakan Lahan Dan Ketahanan Pangan Terhadap Prioritas Pengembangan Kawasan Periurban Kabupaten Bantul. Jurnal Riset Daerah Vol. VIII, No.1. April 2009. 